\title{
The Hegelian Tragedy, Negative Dialectic and Ethical Substance in Sophocles’ Antigone
}

\author{
Ying-shan CHEN \\ National Taiwan University, Taipei, Taiwan
}

\begin{abstract}
Breaking with Aristotle's theory of tragedy in which the grand magnitude of the spirit of the tragic hero somehow trapped and misguided by a certain tragic flaw arouses the audiences' emotional intensity of pity and fear for the functioning of catharsis, Hegel analyzes the structure of tragedy in terms of the social conflict, in the case of Sophocles' Antigone, between the ruler Creon and the rebel Antigone, the patriarchal state and the individual woman, the civil codes and the divine law. Rejecting Creon's dictatorship and performing civil disobedience, Antigone intentionally buries the dead body of her brother Polyneices at the cost of being sentenced to death. Through this sacrifice, Antigone exposes the structural fissure of the civil society embedded in decaying morality for realizing the higher ideal of divine law and ethics. Through Antigone’s sacrifice, the paradox of self-denial and self-elevation manifests the inner principle of dialectic through which the very opposite forces of contradiction engender the dynamic facets of the formation of modern civil society. As Hegelian dialectic is driven by its inner principle of negativity or negation of negation, through self-denial, Antigone transcends the moral codes of the mundane world for reaching the higher divine will. Yet, this dialectical ascending does not indicate a transcendent hero beyond the human world; instead, through the means of self-denying sacrifice, Antigone accomplishes the purpose of the divine will and conveys the divine spirit incarnated in the human flesh. For Hegelian tragic hero, the external and internal conflicts lead to the realization of self-consciousness and the ultimate consummation of heroic identity. Instead of being conditioned by Aristotelian tragic flaw and unconquerable fate, for Hegel, Antigone explicates the modern rebellious spirit of free will, and this martyrdom, not in the sense of scapegoat as the passive substitute for the sin of collective human community, presents a modern sense of tragic hero, an incarnated flesh invested with politically radical spirit. The flesh figure of heroine Antigone exemplifies the immanent power of ethical substance and dialectically transforms the divine will into the earthly spirit. Thus, this paper aims to investigate into the shift from Aristotle's concept of tragic hero to Hegelian dialectic tragedy and further examines how Hegelian tragic hero engenders the historical move into Western modernity through negative dialectic and accomplishes the self-other positioning of ethical substance presented in Sophocles’ Antigone.
\end{abstract}

Keywords: Sophocles’ Antigone, tragedy, Aristotle, Hegel, negative dialectic, ethical substance

\section{Introduction: Aristotle's Concept of Tragedy vs. Hegel's Concept of Tragedy}

Aristotle's concept of tragedy establishes the canonic foundation in which the grand magnitude of the spirit of the tragic hero somehow trapped and misguided by a certain tragic flaw arouses the audiences' emotional intensity of pity and fear for the social functioning of catharsis, known as the purification of soul. In

Ying-shan CHEN, Ph.D. candidate at Dept. of Foreign Languages and Literatures, National Taiwan University, Taiwan. 
Poetics, Aristotle defines tragedy as:

Tragedy, then, is an imitation of an action that is serious, complete, and of a certain magnitude; in language embellished with each kind of artistic ornament, the several kinds being found in separate parts of the play, in the form of action, not of narrative; through pity and fear effecting the proper purgation of these emotions. (p. 10)

As Aristotle defines, tragedy in ancient Greece presents “an imitation of [a tragic hero’s] action,” through which the spectators identify with the hero's spiritual magnitude and simultaneously arouses emotional pity and fear for the sorrowful sympathy with yet dread for the inevitable, doomful fate of the hero. As the tragic action manifests the very autonomous, free will of human agent, the inevitable fate discloses the ultimate circumstance of human condition and finitude. Thus, the spectators arouse the emotional intensity of pity for the common pathos of human beings and the philanthropist brotherhood, and on the other side, the sense of inevitable doom as the universal human condition engenders the other kind of emotional intensity of fear. The fear of inevitable fate takes its core importance in Greek tragic drama. Willis enlists the typical characteristics of classical tragedy, as Greek tragedy first,

depicts the misfortunes that befall human beings, usually centers on a tragic hero, defined by Aristotle a noble, male character who is involved in serious events often with broader social and political repercussions. This tragic hero has many good qualities, but also a fatal flaw leading to a major error of judgment which hastens the tragic events. The journey to disaster and loss has an inevitable feel about it; the tragic hero often has the moment of insight just before his death which makes the ending even more poignant. The spectator experiences a sense of relief in witnessing such great suffering (this is called catharsis). (p. 56)

Willis's enlisting describes the main features of classical Aristotelian theory of tragedy; this classical tragic hero undergoes certain phases and conditions and constructs a typical pattern: a great man with good qualities and high status is inevitably misguided by a certain fatal flaw, and only at the last moment of death can he realize the inconvenient of the doomful fate. As Aristotle's Poetics establishes the canonic foundation of the literary principles of tragedy, Hegel's Aesthetics intends to opens up a new conception of tragedy and invests tragedy with its modern sense. Roche explains:

Most interpreters of tragedy, beginning already with Aristotle, focus their accounts of tragedy on the effect of tragedy, on its reception. Hegel, along with Holderlin, Schelling, and Peter Szondi (1929-79), is one of the few figures in the tradition to make a different path.... The history of the philosophy of tragedy is marred by an overemphasis on reception, an undue focus on the (emotive) effect of tragedy at the expense of tragic structure. Hegel, on contrast, focuses on the core structure of tragedy. Hegel does share with Aristotle an interest in organic plot, with an appropriate reversal and an ensuing recognition, but Hegel's aspiration for organic structure may be said to exceed Aristotle's: Hegel places far more emphasis on the way in which the hero's flaw must be intertwined with, and in a sense results from, her [Antigone's] greatness. (p. 54)

Roche explains that the difference between Aristotle's classical theory of tragedy and Hegel's modern theory of tragedy lies in the former's emphasis on emotional reception and digestion of the audience in catharsis in contrast to the latter's analysis of "the core structure of tragedy," not merely in terms of the organic structure of the text and plot but also in terms of how the social structure of contemporary Greek era is constructed. Thus, for Aristotle, the tragic hero trapped by the inevitability of tragic flaw is preconditioned by destiny and fate. Yet for Hegel, if there is one intrinsic quality of the hero that is called tragic flaw and leads to the end of self-destruction; this tragic flaw is not conditioned by the universal fate but is particularly the product or byproduct of current social structure within a certain historical context. The social structure of Greek 
polis presented in Antigone encounters great challenges and changes, and tragedy foresees and presents the historical transition into a new modern world, and this historical transition can be explained from the social structure for the understanding of a modern sense of human condition. As Frederic Jameson explains:

I do side with those who follow the later Hegel insistence on the necessarily equivalent positions of Antigone and Creon, and on the implication that tragedy always presupposes as irresolvable historical conflict between two forces that destroy each other. For on Hegel's reading, not only is Creon himself destroyed along with his victim, but with both the very form of the polis is itself irredeemably shattered (necessarily giving way to that very different expansion of a single triumphant city-state into the Roman Empire). The tragedy called Antigone is therefore a contemplation of history as such, in all its most irreconcilable singularity: no synthesis can come of this moment, no optimistic theodicy can encompass it, not even the success story of the State as such; Antigone testifies to the existence of problems that cannot be solved, and as such utterly invalidates the myth of Hegel as a teleological thinker. (p. 79; my emphasis)

As Jameson points out, Hegelian "tragedy always presupposes as irresolvable historical conflict between two forces that destroy each other," the two oppositional forces cause the social fissure. As the play unfolds, the destruction of Creon also implies that the "very form of the polis is itself irredeemably shattered and human history transits from Greek city-state into the Roman Empire. As "a contemplation of history as such” (p. 79), for Hegel, Sophocles' Antigone predicts the crucial and significant moment of historical transition and evolution while the existence of the problem (known as the conflicting social fissure of Greek polis) cannot be solved.

The modern sense of Hegel's account of Antigone, for Jameson, is almost synonymous with secularization, "secularization (or modernity)" (p. 86). Thus, some questions will be raised. First, as the modern sense of Hegelian tragedy presents itself as a contrast to Aristotle's classical sense of tragedy, does it imply that Aristotelian tragedy, which derives from Greek culture in antithesis to Christian culture, is pre-modern and barbarian? Second, following the notable discussion of the confrontation between the divine law and the human law in Hegel's reading of Antigone, how can be the divine law explained while Hegel intends to bring to a modern, secular instead of sacred, religious sense of tragedy? Greek tragedy always involves the motif of fate, the ultimate human circumstance and condition when confronting the unknown, infinite power. The struggle between human will and its failure, between human freedom and enslavement unfolds the very theme of tragedy, namely, the ultimate human condition of encountering with fate. In other words, the point that differentiates Hegelian modern sense of tragic hero and Aristotelian classical, pre-modern sense of tragic hero lies in the concept of fate. Because of the dominant, overwhelming and un-controllable power of fate, the hero driven by intrinsic, unconscious trait of tragic flaw realizes his pre-destined condition and finite vision. It is not the tragic flaw within the tragic hero that leads to the understanding of the overwhelming power of fate; but fate itself prefigures and conditions the inevitability of tragic flaw and human finitude. Prior to encountering fate, the tragic hero cannot realize his real and ultimate human condition and goes through the life of redemption (as the case of Oedipus can be one example to explain Aristotelian concept of tragic hero, the tragic flaw and fate). Thus, though the tragic hero as the man of nobles takes his high position and grand magnitude of character and spirit in the earthy, human world, the hero is inevitably driven to self-destruction for the deeper understanding of self-identity and the tragic flaw, an intrinsic trait by destiny. Yet, for Hegel, the understanding of tragedy no longer starts with the concept of tragic flaw but the fissure of social structure and how this asymmetrical power of fissure leads to the historical transition and evolution. Antigone is therefore a case that explains how the ancient Greek polis faces the moment of its social conflicts in the expression of the confrontation between the 
ruler Creon and the rebel Antigone, the patriarchal state and the individual woman, the civil codes and the divine law. Rejecting Creon's dictatorship and performing civil disobedience, Antigone intentionally buries the dead body of her brother Polyneices at the cost of being sentenced to death. Through this sacrifice, Antigone exposes the structural fissure of the civil society embedded in decaying morality and realizes the higher ideal of the divine law and ethics.

\section{Hegel's Tragedy as Negative Dialectic, Ethical Substance and Secularization/Modernization of Human Will}

Thus, in terms of the characterization of tragic hero, Antigone can no longer be taken as the typical tragic hero in the Aristotelian sense, for the very autonomy and determined free will within Antigone disregards the overwhelming unknown power of fate that pushes toward his Father, Oedipus and causes his passive self-destruction. As Hegel's reading of Antigone is quite influential, inclusive of Jacques Lacan's psychoanalytical reworking on Hegelian theory, Judith Butler's synthesis of Hegel's and Lacan's discourses in Antigone's Claim, and Frederic Jameson's reinterpretation of Hegel's significance of interpreting Antigone, the very significance of Hegel's reading of Antigone lies in his bringing new sense of tragedy in terms of, not the unknown, supernatural power of fate that conjures the birth of the tragic hero, but the structural fissure between the individual and the social formation of polis in ancient Greece that engenders the formation of the tragic hero, and how this individual can represent the collective human consciousness and engender the historical evolution into a new phase. Thus, Hegel's direction of reading Antigone can be understood from his ontological system, as Phenomenology of Spirit explicates the evolution of mind from its primary, initial stage to the ultimate fulfillment of spirit; Antigone for Hegel is a perfect demonstration of how an individual human realizes the collective human consciousness and spirit of modern liberty, and how this infinite spirit (in Hegel's terms, synonymous with the divine will of the infinite) realized itself in the world of human history. As Hegel thinks the play demonstrates "a straightforward conflict of interest between the state and the individual, Creon acting in the best interests of the state, while Antigone listens to her conscience and does what she knows to be right" (Dromgoole, p. 16), Antigone as a tragic heroine with strong determination takes the heroic action of redeeming the dignity of her dead brother and making the realization of divine will at the cost of losing her life. Thus, Hegel's concern about Antigone includes first, how the tragic ethos and dialectical structure of ethical modes correspond to Sophocles' world view and human condition, and second, how Antigone’s political agency, subjectivity and autonomy are established through her mourning and caring for the dead. Thus, tragedy is no longer the mourning for the dead, but the pathos for the bravery of the tragic heroine, Antigone.

Therefore, the understanding of the formation of modern tragic hero, or what the modern sense of Hegelian tragic hero is can be explained from first, dialectic as negativity as self-alienation and second, Hegel's ethics or ethical substance as immanence manifested in Phenomenology of Spirit. Hegel explains:

Spirit is, in its simple truth, consciousness, and forces its moment apart. Action divides it into substance, and consciousness of the substance; and divides the substance as well as consciousness. Substance, as the universal essence and End, stands over against the individualized reality; the infinite middle term is self-consciousness which, being the implicit unity of itself and substance, now becomes that unity explicitly and unites the universal essence and its individualized reality. The latter it raises to the former and acts ethically, the former it brings down to the latter and realizes the End, the substance which had an existence only in thought. It brings into existence the unity of its self and substance as its own work, and thus an actual existence. (p. 265) 
Hegel's Phenomenology of Spirit demonstrates the evolution of the stages of mind from its initial state of sense-certainty, to perception, to force and understanding and at the crucial moment, consciousness transits into self-consciousness for the ultimate realization of absolute spirit. The crucial stage of consciousness transforming into self-consciousness is also the moment of self-alienation. As Hegelian regards history as the teleological purpose, the ethical act of the tragic hero is teleological for the realization of human consciousness and for the completion of world history. In other words, Antigone can be regarded as the historical means through which the ultimate historical end of absolute spirit can be expected and fulfilled in the future. The very power of historical evolution can be exercised through the figure of tragic hero, a human flesh of substantial mind, body and act. Antigone utilizes herself as the means of historical transition and completion. Hegel further argues how the moment of consciousness transits into self-consciousness:

In this separation of the moment of consciousness, the simple substance has, on the one hand, preserved the antithesis of self-consciousness, and on the other hand, it equally exhibits in its own self the nature of consciousness, viz. to create distinctions within itself, exhibiting itself as a world articulated into its [separate] spheres. It thus splits itself up into distinct ethical substance, into a human and divine law. Similarly, the self-consciousness confronting the substance assigns to itself according to it nature one of these powers, and as a knowing, is on the one hand ignorant of what it does, and on the other knows what it does, a knowledge which for that reason is a deceptive knowledge. It learns through its own act the contradiction of those powers into which the substance divided itself and their mutual downfall, as well as the contradiction between its knowledge of the ethical character of its action, and what is in its own proper nature ethical, and this finds its own downfall. In point of fact, however, the ethical substance has developed through this process into actual self-consciousness; in other words, this particular self has become the actuality of what it is in essence; but precisely in this development the ethical order had been destroyed. (p. 266; my emphasis)

The Hegelian notion of ethical substance links to the self-consciousness of this subjective mind of hero. This subjective mind of self-consciousness breeds the spiritual character of the tragic hero. In Antigone, the moment of self-consciousness is her awareness of separation from the king, Creon. For the sake of moral justice, Antigone claims her determination of realizing the divine laws, "the great enduring laws of the immortals” in confrontation with Creon's dictatorship buttressed by the civil codes of Greek polis. As Antigone claims:

Antigone: Yes. It wasn't the law of Zeus I broke.

Your decree laughs in the face of justice.

Its perfectly simple: you have no right

To pass such laws. You're just a little man,

And you will die. How can you overturn

the great enduring laws of the immortals?

You can't rewrite them when you feel like it!

For yesterday, tomorrow and today

Dissolve within the greatness of their will,

There's nothing brave in standing up to you.

I'm far too scared to break my God's laws.

Of course I knew that you'd put me to death:

It really didn't need a sham decree.

It doesn't matter so much as I die,

The sooner the better in fact. My pain

Is as wide as the sea; I want to die.

I do not want to see my mother's son

Stretched naked in the field and his white flesh 
Pulled at by dogs. That I could not endure.

Do you think I am a fool. Creon? Perhaps.

But then fools see fools everywhere, don't they?

Chorus: It's clear she gets her fierceness from her father.

He never taught her to yield to bad luck.

Creon: The will that too rigid often breaks.

Iron shatters if it cannot bend.

A tiny whip can tame the wildest horse.

Can you be a man and let yourself be a crowd?

This woman knew exactly what she said.

The law was as clear as glass, she shattered it

And stuck the fragments round her laughing head

To glitter like a crown. Let her go? No!

The she would be the man, not me. Do I

Care that she's the daughter of my late sister?

It would be no different of she were

Every member of my family

Rolled into one. She and that sister of hers

Must suffer the full rigor of the law. (p. 37)

For Antigone, the divine law as the realm of the infinite power represents higher ethical substance than the rigid and fabricated civil codes formulated by the monarchic rulers. Through self-sacrifice, Antigone exposes the structural fissure of the civil society embedded in decaying morality and realizes the higher ideal of the divine law and ethics. In Antigone's sacrifice, the paradox of self-denial and self-elevation manifests the inner principle of dialectic through which the very opposite forces of contradiction engender the dynamic facets of the formation of modern civil society. As Hegelian dialectic is driven by its inner principle of negativity or negation of negation, through self-denial, Antigone transcends the moral codes of the mundane world for reaching the higher divine will. As Jameson explains:

It would seem that for Hegel we must imagine those first human collectivities that precede the emergence of organized societies as mere 'simple substance': they have as yet no articulated content, since content can only be generated by differentiation itself. Such social groups are something like the collective equivalent of that abstract reason or abstract unity we have already confronted in figures like epistemological consciousness or that empire in which there exists only one individual (the despot). (p. 80)

Antigone's act of alienating from the collective other is also the act of differentiating her heroic individuality, through which the heroic consciousness, being mediated by the oppositional forces of dialectic, transforms from the simple substance to the higher realm of the absolute, infinite spirit. For Jameson, the social group as the collective community needs the mediating alienation and differentiation of the tragic hero; through the hero's self-consciousness and determination of self-denial and sacrifice, the collective consciousness can become "concrete," not abstract reason.

Yet, this dialectical ascending from the mundane civil law to the supreme divine law does not indicate a transcendent hero who moves beyond the human world; instead, through the means of self-denying sacrifice, Antigone accomplishes the purpose of the divine will and conveys the divine spirit incarnated in the human flesh. For Hegelian tragic hero, the external and internal conflicts lead to the realization of self-consciousness and the ultimate consummation of this heroic identity. This process of identity-formation and self-consciousness requires self-alienating from the collective others and the symbolic system, through which 
the heroic spirit presented as otherness-with-self, namely, an individual self becoming the alien or the radical other, attributes to its incarnation in the human world. Jameson explains:

Hegel seems to mean that an internal split or schism betokens the interiorization of a conflict that would otherwise have remained external and have opposed two radically kinds of groups... This first practical political of 'One into Two' can thus be seen as an attempt to replace transcendental difference with an immanent one. (p. 80)

As this "One into Two" refers to Hegelian dialectic, namely, how consciousness everlastingly splits into self-consciousness, this self-evolving process of dialectic manifests itself as immanent dialectic.

The moment of self-conscious rebellion against the monarchic system engenders the heroine's suffering. Roche thinks the suffering of the hero does not intend to win the spectators' emotional identification in Aristotle's schema but manifests a heroic determination of self-conscious sacrifice and martyrdom for realizing the ethical substance, an ethical act in suffering, annihilation and transformation. He argues:

Paradoxically, Hegel's focus on the structure of tragic collision gives him a new angle on the traditional motifs of pity and fear. For Hegel, the audience is to fear not external fate, as with Aristotle, but the ethical substance which, if violated, will turn against the hero. Insofar as suffering flows inevitably from the tragic hero's profound identification with a just and substantial position, suffering for Hegel is not quite the undeserved suffering that for Aristotle elicits pity. Hegel reinterprets pity as sympathy not merely with the suffering hero as sufferer but with the hero as one who, despite her fall, is nonetheless in a sense justified. According to Hegel we fear the power of an ethical substance that has been violated as a result of collision, and we sympathize with the hero who, despite having transgressed the absolute, also in a sense upholds the absolute. Thus, Hegelian tragedy has an emotional element: we are torn between the value and destiny of each position; we identity with the character's action but sense the inevitable revenge of the absolute, which destroys the hero's one-sidedness. (p. 54)

Roche here emphasizes the difference between Aristotle's and Hegel's tragic hero in terms of the common ground of the absolute, namely, the divine power. Yet, as Aristotle implies the divine power as fate, yet for Hegel, the ultimate goal or the teleology of history of reaching the absolute is not determined by fate but by the ongoing evolution of human consciousness. The suffering experiences that the tragic hero undergoes "substantiate" the elevating spirit of the tragic hero; the very conflicting struggle within the mental and physical affliction of the tragic hero designates this one consciousness into its doubling of self-consciousness. The collision between Antigone and Creon can be explained as an outward conflict, yet there is more powerful conflict within the consciousness of Antigone, as the story unfolds:

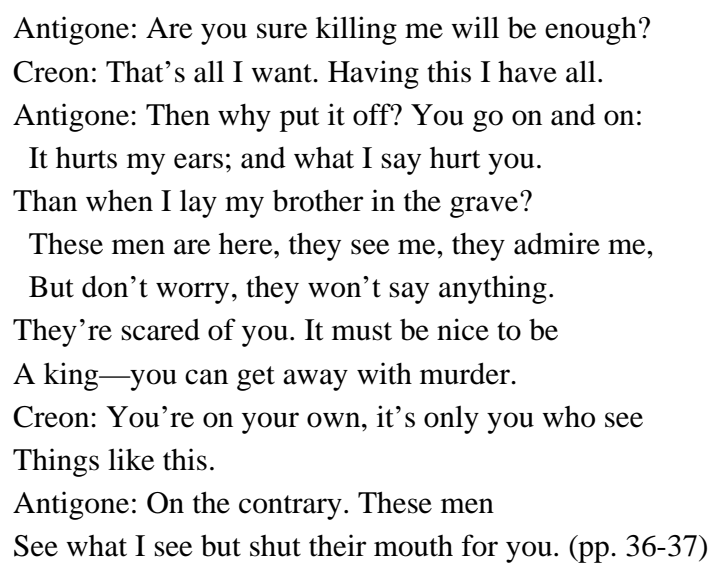

As the majority of Greek citizens are succumbed to the dictatorship of the ruler Creon, Antigone, being 
alienating from the collective society, gathers up her ultimate determination to disobey Creon's order and buries the dead body of her brother Polynices for the preservation of her familial bond, since "for the Greeks, until the body is properly disposed of with religious rites the soul cannot leave and enter Hades. It was therefore the duty of a family to ensure this was done” (Dromgoole, p. 16). The chorus presented as the public opinion under Creon's monarch has warned Antigone yet in vain, for Antigone's firm determination of self-sacrifice even pushes to her encounter with Death. The chorus warns Antigone:

Chorus: You've overreached yourself, Antigone.

You have dared to humiliate the law.

Now justice sends you tumbling and your fall

Is terrible. You must pay for a deed

That your fathers have done.

Antigone: Do not say that,

Do not touch that place of pain in me;

At the place where three roads meet, my father

Met his fate and the treble disaster

Of our family; he murdered his father,

He married his mother, and then had us.

Four shoots from their incestuous loins.

I too rise from their curse and I walk marked,

My own tomb void, to live with my parents.

Ah Oedipus, father, my brother too

In dying you destroyed my life.

Creon: What a dreadful display of self-pity.

It's no use. Weeping and wailing won't fool Death.

Take her away and put her in the tomb

As I've ordered. Seal her in and leave her.

Leave her and walk away! The choice is hers

To die or live, entombed, apart, alone.

Let no-one day this girl has been mistreated.

We proceed knowing what we do is right.

All we say is this: she can no longer

Be with you and me, here on earth above.

Antigone: I move now to my tomb, my bridal bed.

I go to see my family again,

My own people. So many of them dead,

It's time to turn the key and shove the door.

They're getting ready on the other side.

The doorway is most terrible for me.

I go last and far too young but I hope

You'll kiss me soon father, mother, brother.

You must, Polynices, since I washed you,

Adorned you and poured libations on your grave

And this is my reward for loving you.

Some people, decent people, brave people

Think that I did right. I tell you frankly,

Never would I do this for a husband;

Nor would I dare this, even for my child.

Only for you, Polynices.....Why so?

My husband could die and I could marry, 
My child could die, my womb could bear another

But Oedipus and Jocasta cannot

Make another brother for Antigone. (pp. 49-50)

After reflecting on her past family history and a long conversation with the chorus and Credo, Antigone shows her strong determination of self-sacrifice. Roche explains the moment of Antigone's death is the moment of the formation of divine will and spirit. Only at the moment of the fall of the tragic hero, the conflict would be resolved and the historical evolution transits into a new phase, as Roche explains:

For Hegel, tragedy is the conflict of two substantive positions, each of which is justified, yet each of which is wrong to the extent that it fails either to recognize the validity of the other position or to grant it its moment of truth; the conflict can be resolved only with the fall of the hero. (p. 52)

Also, the moment of the flesh decaying in death of the tragic hero signifies the sublimation of flesh body, since for Hegel, Antigone bears witness to a "dialectical transformation of Spirit; the tragedy stages the end of ethical custom and the birth of a historically unprecedented tension between a discrete, self-interested citizen and the norms embodied in the state's legal forms” (Penney, p. 142).

After Antigone's death, Creon faces the fate of self-destruction. Though being a king of omnipotent power, Creon cannot escape the fate of the mortals-Death.

As the play unfolds:

Teiresias: Then hear me, Creon.

Few will be the circuits of the sun

Ere you must yield your seed to those below.

Death is mocked you send him her that lives,

Death is mocked you hold his dead above.

You keep your living, but Death wants his dead.

The God demands you pay for both these crimes

With fruit that springs from forth your mortal loins.

“A corpse for a corpse!” Hades thunders

And he will have his way for you have done him

Violence; your doom is inescapable.

Even the Gods are powerless to change

Your fate: it is the inevitable

Consequence of all that you have done. (p. 54)

Defying the divine will that Antigone intends to perform, Creon also faces the fate of losing his life possession in the mundane world-his son, wife, crown and life for taking the full responsibility for the consequence of breaking the divine will. The Chorus continues to chant:

Chorus: Release the woman from the tomb below,

And bury the man who remains exposed.

Creon: Do you really think it's right to yield now?

Chorus: Yes, Creon, quickly, you haven’t much time;

When the Gods send the Furies, they run fast.

Creon: This is hard. I must submit. I must change.

I cannot fight against necessity.

Chorus: Do not entrust this to others, Creon.

Quickly go yourself.

Creon: Yes, I will go now. 
Come with me, servants! Follow me quickly.

Take axes and shovels, run for your lives

To that strange place where I have buried her.

With my own hands I must free Antigone.

For I would rather live and die

Within the frame and structure of the law. (p. 55)

Knowing the punishment he needs to accept for redeeming the deprived innocence of Antigone, Creon is willing to release the buried body of Antigone. Yet, such compensation cannot redeem the mistake of defying the divine law; at the end of the play, Creon witnesses his fate of being deprived of all his possession in this earthly world:

Enter Creon with the body of Haemon.

Chorus: Here comes the king, his child limp in his arms.

He knows what he has done.

Creon: Oymoy. Oymoy. Madness. Madness. Madness.

So stubborn, so blind, so vain. Look at us!

Family who have eaten each other.

Oyoyoyoyoy! All I have done is evil.

Ah my son, my young dead boy!

Ay ayayayayay! You died, I killed you.

I alone am responsible.

Chorus: Oymoyoyoyoy! You see the truth too late.

Creon: Oyoyoymoyoyoy!

I suffer. I learn. A high God did this:

He took a great load and dropped it on my head,

Then he cast me into unknown places,

Wild paths. Oymoy. He threw me upside down.

Pheupheupheu. How we suffer; people suffer...

Creon: I want to pray.

Chorus: Do not want anything.

There is no escape from your fate.

Creon: My son-I killed you, my wife-I killed you.

I do not know which one of you to see.

I do not know which way I ought to go.

All is warped that is in my hands, and upon my head

And unbearable fate has leapt.

Chorus: Happiness is born in wisdom.

When we deal with the Gods

We must behave with piety.

The great words of the proud

Are punished with great blows.

We learn this as we grow old.

The End. (pp. 61-62)

\section{Conclusion}

The oppositional forces between Antigone and Creon for Hegel presents the social conflicts and fissures in Greek city-state and the death of the monarch Creon, following Antigone's death, makes a historical transition into a new epoch. This opposition also marks the crucial moment of world history in which "the position of 
heroes generally; through them a new world dawns. This new principle is in contradiction with the previous one, appears as destructive; the heroes appear, therefore, as violent, transgressing laws. Individually, they are vanquished; but this principle persists, if in a different form, and buries the present” (Roche, p. 52). By means of transgressing the long-established social norms, the tragic hero presents himself or herself as the archetypal figure who marks the generation of a new historical era and engenders the progression of historical evolution.

\section{References}

Aristotle. (2008). Poetics. S. H. Butcher, (Ed.). New York: Cosimo Classics.

Anderson, P. (1997). Re-reading myth in philosophy: Hegel, Ricoeur and Irigaray reading Antigone. Paul Ricoeur and narratives, context and contestation. M. Joy, (Ed.). Calgary: Univ. of Calgary Press.

Butler, J. (1983). Antigone's claim: Kinship between life and death. New York: Columbia U.P.

Hegel, G. H. W. (1975). Aesthetics: Lecture on fine art. Vol. II. (T. M. Knox, Trans.). Oxford: Oxford U.P.

Hegel, G. H. W. (2005). Phenomenology of spirit. (Y. Yovel, Trans.). NJ: Princeton Univ. Press.

Jameson, F. (2010). The Hegel variations: On the phenomenology of spirit. New York: Verso.

Penney, J. (2006). The world of perversion: Psychoanalysis and the impossible absolute of desire. New York: SUNY.

Roche, M. W. (2005). The Greatness and Limits of Hegel's Theory of Tragedy. In R. Bushness (Ed.), A companion to tragedy (pp. 51-67). NJ: Blackwell Publisher.

Sophocles. (1999). Antigone. (D. Donnellan, Intro. \&Trans.). Oberon Books Ltd.

Willis, A. (2004). Texts through history. London: Routledge. 